\title{
Knowledge Production Beyond Local and National Blindspots: Remedying Professional Ocularcentrism of Diversity in Music Teacher Education
}

\author{
Heidi Westerlund \\ Sibelius Academy, University of the Arts Helsinki, Finland \\ Sidsel Karlsen \\ Inland Norway University of Applied Sciences, Norway
}

In this article, we argue that mainstream discourses of diversity in music education are ocularcentric; that is, they provide a one-sided way of understanding diversity that has prevented music educators from seeing our biases. In remedying these local and national professional blindspots, we propose transnational knowledge production, which we explore through our own experiences in an ongoing research project aiming to co-develop intercultural music teacher education through institutional collaboration. We argue for a heterogenous, kaleidoscopic reflexivity towards diversity that takes into account the complexity of intercultural negotiation through knowledge production, including the ethico-political dimensions of such interactions. We believe such reflexivity to be one of the most important goals for music teacher education today.

Keywords: diversity, interculturality, knowledge production, multiculturalism, music education, ocularcentrism, reflexivity, teacher education

he mainstream diversity discourse in music teacher education has long
been, and still is, that of multiculturalism-a world of ideas which has
quite rightly countered the long-standing hegemony of Western classical music, and that promotes the value of acquiring hands-on knowledge and culture-sensitive understandings of the world's musical diversity. The "multicultural education movement" (Howard, Swanson, and Campbell 2014, 26; see e.g. Roberts and Campbell 2015) celebrates the cultural richness of all localities, nationalities, ethnicities, communities, and identities in its groundedness in the intersections of music, culture, and ethnicity (Campbell 2004; Campbell et al. 2005; Harris 2006; Schippers 2010; Volk 1998). However,

(C) Heidi Westerlund and Sidsel Karlsen 2017. The content of this article is the sole responsibility of the author. The ACT Journal and the Mayday Group are not liable for any legal actions that may arise involving the article's content, including, but not limited to, copyright infringement. 
these celebrations have also resulted in a tendency to further ethnicize and even racialize music by establishing the ethnicity as the main criteria-or political agenda-for musical diversity (Volk 1998). In this way, tying "musical cultures," peoples, and geographical locations together has allowed for simplistic distinctions and labels to be applied to categories of musical knowledge, identities, and experiences. Thus, the well-intentioned aims of multicultural music education to make space for the world's many musical cultures at the same time produces a fixed epistemological picture of world musics, a musical mappa mundi (Karlsen and Westerlund 2015) of how diversity exists in our realities and how knowledge of diversity is produced; in other words, how we should understand diversity in music education. Within the musical mappa mundi, the varieties of knowledge arising from traditions exist harmoniously, and the interaction between cultures in education is simply about giving space for another kind of knowledge, diverse values, and principles, all positive and enriching contributions to the human life.

This dominant multicultural discourse is one not only pertinent to the fields of education or teacher education, but can be seen in the foundations of political and policy decision-making with regards to how people from various cultures should live together (Kymlicka 2010). It appeared on the political and philosophical agenda in the $1960 \mathrm{os}$, in response to migration and with the three principles of liberal democracy: liberty, equality, and unity (Parekh 2016, 266). Central to this was how to accommodate diversity within the unity of the society without violating the liberty and equality of minorities (267). Critiquing this dominant discourse, the sociologist Bauman (2011) notes that while multiculturalism allows for cultural space, it also allows people to remain distinct from one another, and thereby assume that they have "the right to be indifferent to difference" (59). According to him, we ought rather to learn and practice "the art of living with difference" (Bauman 2010, 151), that is, to navigate in a world in which cultural diversity exists and learn how to move between cultures.

Notwithstanding our recognition of the contributions of multicultural music education, we argue that one of the central issues that prevents music educators from fully seeing our biases is the very notion of diversity and the ideological context within which this notion is produced. The mappa mundi of multiculturalist music education, particularly in its simplified form, is not sufficient to tackle the broad range of diversity issues found in today's societies, nor can it adequately guide our responses to the rapidly changing compo-

Westerlund, Heidi, and Sidsel Karlsen. 2017. Knowledge production beyond local and national blindspots: Remedying professional ocularcentrism of diversity in music teacher education. Action, Criticism, and Theory for Music Education 16 (3): 78-107.

doi:10.22176/act16.3.78 
sition of hybrid super-diverse societies (Cantle 2012). The kind of multiculturalism that promotes and preserves the authenticity of musical traditions is insufficient in situations where authenticity can be set against the horizons upon which global ethics insist, as we will point out later in this article. In music education scholarship, the practice-turn, with its emphasis on musical norms and principles, has not helped in this respect (Elliott 1995). Multiculturalism avoids dealing with the fact that not all music- and identity-related diversities in society are exclusively positive or worth celebrating; at least not from everyone's perspective. In other words, musical cultures, or practices, may involve exclusion or unjustified distinction based on, for instance, issues of race, gender, social class, or caste, to name just a few. Multicultural music education has not been dynamic enough to highlight the contextual-social, political, and ethical etc.-situatedness of musical encounters. Such a situatedness determines what is taught, how it is taught, who is considered legitimate as a teacher, and why certain behaviors occur and certain repertoires are preferred or chosen, how the participants' experiences and identities are played out, and how these intersect, blend in fruitful ways, and sometimes collide (Karlsen and Westerlund 2015). In its discursive emphasis, multicultural music education prioritizes distinction and preservation, and thus fails to see the process of knowledge construction as a fundamentally dialogic, coconstructed process towards something new. In other words, such education should not simply be about multiculturalism, or music, but also about education in a critical sense. As a hegemonic ideology of diversity, multiculturalism may indeed obscure forms of inequality and injustice that fall outside of its conceptual frames, and as such we may believe that diversity is "properly taken care of" while, in fact, much remains to be done (Karlsen 2017). The failure of multiculturalism to address social and political locatedness and injustice in music education has been discussed by Bradley (2015) and Hess (2013) among others, both pointing out the insufficiency with which this framework has addressed matters of race. Moreover, as Vaugeois (2007) claims, the discourse of multiculturalism as such "creates definitional exclusion" (173), and has been employed in a much too innocent way in music education, not taking into account its exclusionary properties.

Recognizing the need for a broader transformation of and within music teacher education than simply disrupting the dominance of Western art music traditions, we identify a need to develop a more heterogenous, ethically and politically conscious kaleidoscopic reflexivity in music teacher education as a

Westerlund, Heidi, and Sidsel Karlsen. 2017. Knowledge production beyond local and national blindspots: Remedying professional ocularcentrism of diversity in music teacher education. Action, Criticism, and Theory for Music Education 16 (3): 78-107.

doi:10.22176/act16.3.78 
response to what we in this article call "ocularcentrism of diversity." By ocularcentrism of diversity we refer to an understanding of diversity in music education that is based on categorization and classification, which is accomplished through "naming and ordering, taxonomization, that turns difference visible, seen and perceived in particular ways" (Ahonen and Tierari 2015, 273). Through a more kaleidoscopic approach, we may better tackle the dynamics of diversity that influence knowledge production in music education more generally (Westerlund 2002, 224; see also, Abdallah-Pretceille 2006; Laes 2017). We also propose that diversity could be approached from the perspectives of cross-cultural dialogue, intermingling and interaction, rather than cultural categorisation (Meer, Modood and Zapata-Barrero 2016). Our epistemological argument is that instead of perceiving the dissemination of the plurality of musical traditions as a conceptual "end-station" for tackling diversity, we need to develop a more wide-ranging form of reflexivity and critical contextuality to contest prevailing practices independent of whose practices are in question. Furthermore, we see a need to include countries from the majority world (Dasen and Akkari 2008) ${ }^{1}$ in scrutinizing the application of the 'multicultural view' of diversity in music education, which was developed within the North-American discourse, but has spread to the worldwide professional field. Moreover, we see that music teacher education needs to play a crucial role in developing this kind of reflexivity, which produces more than new musical skills (without underestimating the importance of these). In order to see beyond musical sounds and diverse musics, as presented by the multicultural music education movement, we identify a need to intensify the existing work against the musico-pedagogical practice model that can surely embrace musical diversity through advancing practice-specific musical knowledge, skills, and even pedagogies (see e.g. Elliott and Silverman 2015; Georgii-Hemming, Burnard and Holgersen 2013), but pushes the profession towards the sustenance of the past and preservation of traditions (Westerlund 2017). Thus the musico-pedagogical practice model may improve existing practices from a musical perspective but may prevent us from envisioning other aspects of what quality might mean in music education (Laes and Westerlund 2017).

\section{Global visions through transnational collaboration}

We construct our argument in this article against the backdrop of an ongoing transnational collaborative research project which is grounded on the hypoth-

Westerlund, Heidi, and Sidsel Karlsen. 2017. Knowledge production beyond local and national blindspots: Remedying professional ocularcentrism of diversity in music teacher education. Action, Criticism, and Theory for Music Education 16 (3): 78-107.

doi:10.22176/act16.3.78 
esis that one effective way for teacher education to respond to the 21st-century challenge of diversity is through actual hands-on collaboration and "learning from each other" within and beyond institutional and national borders (Darling-Hammond and Lieberman 2012). The project, Global visions through mobilizing networks: Co-developing intercultural music teacher education in Finland, Israel and Nepal (hereafter Global visions) aims to develop music teacher education across local and national borders through an expanding international network of music teacher educators and researchers from the Sibelius Academy of the University of the Arts Helsinki, the Levinsky College of Education in Tel Aviv, and the Nepal Music Center in Kathmandu. ${ }^{2}$ The collaboration between the Sibelius Academy teachers and the Nepal Music Center (NMC) was initiated by an informal request from two NMC leaders to one Sibelius Academy professor to assist their institution in building music teacher education, as such education did not yet exist in Nepal. This collaboration was initiated first through a teacher educators' exchange project and was later continued and greatly expanded as part of the ongoing Global visions research project in which two doctoral and two postdoctoral researchers and two professors facilitate mutual co-construction of knowledge and thus building teacher capacity in Nepal Music Center, Kathmandu Valley schools, as well as at the Sibelius Academy. In this work, NMC teachers and other music teachers are heavily involved as co-constructors on all levels, practical and theoretical (see e.g. Shah, Tuladhar, Shrestha and Karki 2017; Treacy, Neupane and Thapa 2017; Treacy, Timonen, Kallio and Shah forthcoming).

While Global visions encompasses several sub-studies in which data collection takes place, it is not primarily an empirical project. Rather, it is a project in which the outcome of the interaction and collaboration between the different partners is thought to corroborate its grounding hypothesis. While data and data analysis are used to address the specific research questions in sub-studies, these studies, based on collaboration and co-construction of visions, serve as the starting point for our aim to theorize. Practice-driven theorizing is conducted by many of the contributions from all 15 researchers involved in Global visions (see e.g. Karlsen, Westerlund and Miettinen, 2016; Treacy, Timonen, Kallio and Shah, forthcoming), including this article. Other outcomes include the enacted transformations to higher music education practices based on the hybrid knowledge produced within the substudies and brought back into the collaborating institutions by the scholars conducting this particular part of the research (see e.g. Miettinen, Gluschankof and

Westerlund, Heidi, and Sidsel Karlsen. 2017. Knowledge production beyond local and national blindspots: Remedying professional ocularcentrism of diversity in music teacher education. Action, Criticism, and Theory for Music Education 16 (3): 78-107.

doi:10.22176/act16.3.78 
Westerlund 2016; Timonen, Juntunen and Westerlund 2017). Consequently, Global visions is not a project limited to addressing challenges in the Finnish, Israeli, or Nepali educational contexts per se. Rather, the project, with its teacher educators' network, is dedicated to co-developing knowledge for music teacher education on how to deal with the challenge of equipping future music teachers.

Our view here is not so much all-inclusive as dynamic and contextually changing. While critiquing the multicultural paradigm and the related signifiers of ethnicity and race that are characteristic of the multicultural discourse, the management and leadership scholars Ahonen and Tienari (2015) claim that many of the perspectives on diversity are "ocularcentric" and "panoptical," through their reliance "on observations, perception and recognition driven by one particular way of seeing and perceiving" (280). The term panoptical refers to one of the techniques of knowledge that Foucault (1977) took from Jeremy Bentham's architectural design Panopticon in the mid-19th Century. Foucault used Panopticon as a metaphor to explore the relationship between systems of social control and people in a disciplinary situation, and the power-knowledge concept. According to Foucault, the Panopticon

is an important mechanism for it automatizes and disindividualizes power. Power has its principle not so much in a person as in a certain concerted distribution of bodies, surfaces, lights, gazes; in an arrangement whose internal mechanisms produce the relation in which individuals are caught up. (Foucault 1977, 231.)

Panopticon is "polyvalent in its applications" and the schema can be used "whenever one is dealing with a multiplicity of individuals on whom a task or a particular form of behaviour [such as musical behaviour] must be imposed" (225). In this context, the ethico-politics of diversity, it does not matter who defines diversity, as the panoptical gaze produces diversity out of difference discursively. Importantly, as Ahonen and Tienari argue, even the critical approaches to diversity do not offer solutions unless they interrogate the means through which diversity knowledge is produced and take into account that any production of diversity knowledge is always "dangerous" and should alert us to be vigilant (284).

Translated into the context of music teacher education and music education research, such ocularcentrism might imply that issues of diversity in music education can become known, understood, organised and "managed" through one perspective only, and that is the one adopted in one's immediate

Westerlund, Heidi, and Sidsel Karlsen. 2017. Knowledge production beyond local and national blindspots: Remedying professional ocularcentrism of diversity in music teacher education. Action, Criticism, and Theory for Music Education 16 (3): 78-107.

doi:10.22176/act16.3.78 
context, whether this is local, national or scholarly-international. When this kind of ocularcentrism in music education scholarship transports its "critical" perspective into any educational context, or to transnational and crosscultural interactions, it negates the necessary skills and understandings to work within increasingly diverse environments and to become more reflexive about one's local professional and educational starting points. We therefore draw upon and exchange our context-bound experiences and knowledge, acquired through interaction and hands-on collaboration of music teacher educators in countries and contexts that are significantly different in many ways. This experiential difference-in geographical location, demographics, historical, religious, linguistic, and political circumstance, and intensity of societal diversity-constitutes the biggest asset of the Global visions project. Along with the exchange of experiences and knowledge, we make use of a variety of methodological approaches so as to increase reflexivity of music teacher education that is meant to help us develop the teacher education programs at our own institutions.

\section{Knowledge production at the heart of transnational collaboration}

In what follows, we explore the production of diversity in and for higher music education institutions and music teacher education through the ongoing collaborative activities in the Global visions project, arguing that the politics of diversity may be seen as a form of knowledge. Furthermore, the means by which such knowledge is produced, in this case in transnational interaction and collaboration, are important in terms of how they invite the ethical pitfalls and paradoxes into the realm of reflection (Karlsen, Westerlund and Miettinen 2016). Due to its design and nature, our ongoing research project requires us to identify our own personal and professional understandings, and to constantly and critically re-examine and test these in relation to those in the international and majority-world music education field. Here, we draw upon examples from the Finnish-Nepali collaboration in particular, while striving for self-reflexivity and aiming to highlight the dynamics related to the ethicopolitics of diversity. If applied without investigating its own assumptions, history, and practices, even a critical lens can (re)produce the dynamic of the Panopticon; for instance, labelling "White" music produces and reinforces the boundaries of Blackness, or the critical demand on musical authenticity may prevent aspiring to a different kind of future. Put simply: While race and

Westerlund, Heidi, and Sidsel Karlsen. 2017. Knowledge production beyond local and national blindspots: Remedying professional ocularcentrism of diversity in music teacher education. Action, Criticism, and Theory for Music Education 16 (3): 78-107.

doi:10.22176/act16.3.78 
racism might serve as an entry point for productive criticism of oppression in music education from a North-American point of view (see e.g. Bradley 2007; Hess 2015), it may not necessarily be a relevant lens for investigating social injustice in contexts in which other social dividers are in play, such as ethnicity, caste and gender in Nepal. This may even be the case when it comes to transnational interaction. Enforcing one particular critical lens may instead (re)produce the very forms of inequity we intend to remedy.

More specifically, we reflexively examine some of the conceptual underpinnings that have had an impact on higher education generally and thereby also on music teacher education, through which understandings of diversity have been developed. We also explore how transnational collaboration might push the boundaries of our understanding of diversity and create a wider reflexivity than our normal routinized local practices might allow. The structure of our exploration is threefold. We examine:

1. how various forces push higher education, therein also music teacher education, to become more transnational and diverse, and point out the importance of understanding the varying rationales for crossinstitutional collaboration as a way to respond to the needs and challenges of the increasingly super-diverse societies;

2. how reflexivity needs to be developed through multiple frameworks, including political frames, in order to avoid ocularcentrism of diversity;

3. how the paradoxes that have arisen from transnational knowledge production in the Global visions project call for a heterogenous, ethically, politically, and future-oriented reflexivity of the local-global dynamics of diversity.

\section{Understanding and navigating diversity in changing times}

\section{Internationalization as a higher education policy demand}

The reactions of higher music education to the forces of globalization and the increasing awareness of diversity have varying rationales and are therefore vastly different with respect to their educational outcomes. In general, higher education and universities globally are pushed towards international collaboration, often coined with the more recent term of globalization, in order to provide graduates with the necessary knowledge and skills for working in

Westerlund, Heidi, and Sidsel Karlsen. 2017. Knowledge production beyond local and national blindspots: Remedying professional ocularcentrism of diversity in music teacher education. Action, Criticism, and Theory for Music Education 16 (3): 78-107.

doi:10.22176/act16.3.78 
diverse contexts. As such, international collaboration is not a new approach in universities. In the mid-199os, internationalization was understood "as the process for integrating international/intercultural learning into the teaching and research, and service functions of an institution" (Olson and Peacock 2012, 305). Beyond teacher and student exchanges, some universities follow specific local guidelines for increasing the diversity of the teacher and student populations. This aspect, which emphasizes the rights of minorities, is also present in the evaluation of university profiles, study programmes, and even research projects. Consequently, internationalization has become part of the administrative chores in the form of "managing diversity" (Ahonen and Tienari 2015) in higher education.

Beyond these general university policies, study programmes often include courses that concentrate specifically on issues of diversity, social justice, and multicultural content integration. Some universities have developed programmes in which a large part of the studies are completed at an institution located in another country. One example of such an initiative is the GLOMAS international bachelor's and master's degree programmes at the Sibelius Academy (https://www.uniarts.fi/en/degree-requirements-sibelius-academyglomas), in which the students, coming from many different countries, do not necessarily share any musical tradition; the general aim of the studies is to learn with and from the others as well as in and through various contexts. Internationally, music teacher education programmes often have one course that deals with world music cultures, and to intensify experiences of diversity, some programmes also have courses in which student teachers can travel to foreign contexts to stretch their comfort zones. At our own university, the University of the Arts Helsinki, such exchange programs have been organised for a selected number of students (see e.g. http://mcau.fi/). What these solutions typically share is a positive attitude towards diversity, followed by some clear guidelines for politically correct behavior and language use, paired with instructions of how to avoid former mistakes of colonisation, western interpretations and pedagogies. Importantly, however, in international exchanges, the individual who travels to the new context is expected to change or to move out of personal comfort zones, whereas the exchange as such is not expected to transform the host institutions.

Westerlund, Heidi, and Sidsel Karlsen. 2017. Knowledge production beyond local and national blindspots: Remedying professional ocularcentrism of diversity in music teacher education. Action, Criticism, and Theory for Music Education 16 (3): 78-107.

doi:10.22176/act16.3.78 


\section{Varying political interests in interpretation}

Contemporary sociologists seem to agree that at the global level, our societies change fast, mainly as a result of increasing migration, inexpensive Internet connections, and new media, and the opportunities that these create for increased interaction. According to the sociologist Bauman, in this mobile, unstable, and ever-transforming world, we all either live "in a diaspora" or "among diasporas" (Bauman 2010, 151, italics in original). Vertovec (2007) calls this increasing complexity super-diversity, a condition that "is distinguished by a dynamic interplay of variables among an increased number of new, small, and scattered, multiple-origin, transnationally connected immigrants" (1024). According to Cantle (2012), these changes require the emergence of a new pattern of social identity, a cosmopolitan conception of identity that suggests the development of complex hybrid or multiple identities. This increasing diversity does not mean that it would no longer be important for people "to hang on to their heritage ... but, rather, that there is an overwhelming need to invest more heavily in the development of identities that transcend national, faith, and ethnic boundaries" (187). Consequently, in such an era of super-diversity, it is not possible to simply teach about the boundaries between musical traditions, or search for the essence of any tradition in particular. Instead, boundary crossing in itself, or the exploration of hybridity, could be possible points of departure. We also need to see beyond students' ethnic labels and not to expect that their ethnic heritage is the one they themselves want to perform in the school context (Karlsen and Westerlund 2015; Karlsen 2013).

Hence, this rapid change also creates insecurity and conflicts. In The Power of Identity from 2010, the Spanish sociologist Castells argues that it is this very same complexity of contemporary societies that simultaneously increases fundamentalism. Such a societal form, which shakes institutions and transforms cultures, might also create a sense of "an increasingly unpredictable and uncontrollable life" (Castells 2010, 27). If sociologists argue that identities are less and less associated with tribal and regional affinities (Cantle 2012, 29), this very same process may create a counter-reaction and tension rather than harmonious co-existence of plural understandings of values and cultural forms. Moreover, Cantle (2012) warns that "the pull of national identity should never be underestimated" as "it resonates with many of humanity's deepest instincts and needs" such as security and safety (185-6).

Westerlund, Heidi, and Sidsel Karlsen. 2017. Knowledge production beyond local and national blindspots: Remedying professional ocularcentrism of diversity in music teacher education. Action, Criticism, and Theory for Music Education 16 (3): 78-107.

doi:10.22176/act16.3.78 
Fuelling this unpredictability is also the societal impact of the ideology of neoliberalism, which, among other things, has generated situations of economic instability worldwide and has added another force underpinning rapid and erratic world change. Consequently, while on the one hand the world situation and the overall political picture allow for positive and expansive dynamic interplay between people with diverse backgrounds, on the other hand, it creates conditions for development of the kind of fear and insecurity that might lead to increased xenophobia and a strengthening of the maintenance of ingroup and outgroup distinctions. As such, neoliberal forces, marketization, and privatization also impact on the knowledge production of higher education and can be the driving forces of both internationalization strategies of the university and of intercultural projects whose intrainstitutional legitimization is related to students' employability (see e.g., Zotzmann 2016) as educational exports. These tendencies tend to turn up, for instance, when projects such as Global visions are discussed from the perspective of the leadership of the university.

Higher music education therefore needs to rethink how it responds to the needs and challenges of today's societies. According to Keuchel (2015), there are three dominant patterns of interpretation as regards the interplay of diverse cultures, depending on political interests and control processes, namely polyculturality, interculturality, and transculturality. Of these three, polyculturality is the one that comes closest to the dominant multicultural view, as it "emphasizes manifold different environments and cultures existing side by side in a sphere of mutual perception" (105). In Sarmento's (2016) view, this kind of polycultural concept of multiculturalism prevails in the Anglo-Saxon world, where social integration aims at social cohesion instead of actual inclusion: "Integrating or assimilating migrants is not part of the same national and societal project as creating a society that offers similar opportunities to everyone" (128). In Europe, however, multiculturalism has a more limited meaning than in North America where multiculturalism has involved discrete groups, such as native peoples, also with territorial claims, whereas in Western Europe the term has been more closely linked to post-immigration politics (Meer and Modood 2016, 31). Hence, the interpretation in music education cannot be made without taking into account these discursive meanings and the wider educational policies and politics of the society in question.

The intercultural approach, Keuchel's (2015) second category, which will be expanded upon later in this article, emphasizes "a perspective of dialogue

Westerlund, Heidi, and Sidsel Karlsen. 2017. Knowledge production beyond local and national blindspots: Remedying professional ocularcentrism of diversity in music teacher education. Action, Criticism, and Theory for Music Education 16 (3): 78-107.

doi:10.22176/act16.3.78 
and the interaction between manifold different environments and cultures, as well as the self-definition in relation to the respective other(s)" (106). A growing body of research uses the concept of interculturality to refer to a framework that tries to challenge the kind of multiculturalism that categorizes people through geographical origin, nationality, or ethnicity (Zapata-Barrero 2016; Zotzmann 2016; Karlsen, Westerlund and Miettinen 2016). There are versions of intercultural approaches that take diversity as a resource but fight against stereotypes, "groupism," and social exclusion, stressing that dialogue and integration are two-way processes adapting also to the "super-diversity" of our societies and the multifaceted aspects of difference and "otherness" (Meer, Modood and Zapata-Barrero 2016, 18-19). Moreover, many find that the overemphasis on demarcating differences overshadows the fact that commonalities can penetrate national boundaries, regions, languages, and even religions (Dervin and Gross 2016, 4). School is by no means an exception in this respect. Importantly, as much of the multicultural debates of the late twentieth century have followed a cultural rights-based approach to diversity (Meer, Modood and Zapata-Barrero 2016, 18), which in music education is evidenced in the communitarian tendency to emphasize preservation, the approach has developed a somewhat passive and wary attitude towards change and development of any kind. Some researchers see interculturalism as a response to this bias:

Whereas multiculturalism is concerned with respecting and acknowledging cultural diversity, allowing different cultures to co-exist, and in a sense reinforcing differences, the key feature of interculturality, and what differentiates it from multiculturality, is its sense of openness, dialogue and interaction between cultures leading to long-term change in both relational and institutional arrangements (Cantle 2012, 156).

Thus, researchers see interculturalism as a new interpretation and strategy for integration, social inclusion, interconnectedness, dialogue, interaction and exchange, social cohesion and desegregation (Loobuyck 2016, 225). As such, intercultural education seems to have European origins, while the use of the term can also be traced to Latin America in the 1970s (Meer, Modood and Zapata-Barrero 2016, 3). In music education, the use of the term has been limited, albeit not completely absent, and has involved a heavy critical decontextualization of music. For instance, Keith Swanwick argued in 1988 for an inter-cultural attitude that disregards the notion of music as "ethnic or national flags or as exotic illustrations of a culture" (112) in the time when music's territorial origins have lost their significance and musical processes have

Westerlund, Heidi, and Sidsel Karlsen. 2017. Knowledge production beyond local and national blindspots: Remedying professional ocularcentrism of diversity in music teacher education. Action, Criticism, and Theory for Music Education 16 (3): 78-107.

doi:10.22176/act16.3.78 
become accepted on their own terms. This approach critiqued the "divisive and sometimes racist idea of 'multi-cultural'" (112) by pointing out that school is a particular kind of context for music learning. Today, interculturalism is becoming more commonplace in wider policy documents (See UNESCO World Report Investing in Cultural Diversity and Intercultural Dialogue 2008) as a strategic response to diversity, addressing in particular questions of migration-related diversity (Meer, Modood and Zapata-Barrero 2016, 7).

Keuchel's (2015) third pattern of interpretation, transculturality, implies looking at diversity through lenses which focus in particular on "the fusion and new manifestation processes of different environments and cultures (hybridization) and the possibility of multiple and variable orientations" (106). Such an approach is closely related to our previous efforts to articulate what "the art of living with difference" would mean in music education (see Karlsen and Westerlund 2015). As such, the Global visions project and its aims may be placed conceptually somewhere between interculturality and transculturality, and the knowledge produced within it bears markers of these specific patterns of interpretation, having ideological and political interests that move between exploring more detailed context-specific processes with their developmental actions, and sharing our inter-institutional or transnationally co-constructed knowledge. Through these lenses of institutional dialogue, a merging of horizons and the employment of multiple and hybrid frames for interpretation on a wider transnational level is characteristic.

Yet despite the commonly used distinctions, according to many scholars, multiculturalism could be understood as complementing, not competing with interculturalism (Modood 2016). Despite the simplified interpretations in music education, it should be noted that both political multiculturalist and interculturalist dialogue may be seen as "bi-focal" (Parekh 2000, 271), as they both take into account power structures and aim at wider change in society. Like many others, Sarmento (2016) describes multiculturalism as a subcategory of interculturalism that more strongly aims to "go beyond contemporary circumscribed issues, towards the understanding and fostering of global communication, both past and present" (138). We find it important to recognize that, despite the emphasis of transnational intercultural activities, the understanding of diversity in music education should be developed in relation to the needs of the given locality, nation-state, and wider society. In the battle to fight neoliberal tendencies, it is important to also critically interrogate the paradigmatic epistemological tools and understandings that are supposed to

Westerlund, Heidi, and Sidsel Karlsen. 2017. Knowledge production beyond local and national blindspots: Remedying professional ocularcentrism of diversity in music teacher education. Action, Criticism, and Theory for Music Education 16 (3): 78-107.

doi:10.22176/act16.3.78 
underpin and aid us in the work towards increased intercultural dialogues, asking ourselves from what position we develop such dialogues, with which tools for knowledge creation, and how this can best be fostered within a highly privileged university space.

\section{Developing the frames for understanding the complexity of reflexivity in knowledge-building communities}

We suggest that music teacher education units could redefine themselves as knowledge-building communities, instead of knowledge-transmission units, in which issues of diversity are constantly co-reflected upon in relation to the needs and challenges of the context and the wider society, as well as to international scholarship. The concept of knowledge-building communities, as employed in the Global visions project, is thus one potential lens for developing the large-scale co-creation of transnational and intercultural knowledge that increases reflexivity. As such, knowledge-building communities may be seen as inherently intercultural in that they often "include researchers and teachers with different experiences working in different contexts" (Fishman, Davis and Chan 2014, 712) and "participants from different sectors and different countries" (713). In the context of teaching, knowledge-building communities might resemble the more traditional communities of practice. Yet what they offer in addition is the conscious creation of "new knowledge and practice for the community" (712), a condition of constant critical development crucially important in today's view of what should characterise the teaching profession.

More specifically, the mobilizing network of the Global visions project is conceptualized as a transnational collective third space (a term introduced by Homi Bhabha in 1994, in The Location of Culture), in which new knowledge on music teacher education is not only shared but also produced, contested, and negotiated in relation to issues of hegemony, power relations, and the ethical implications that follow. In the project, our collaborative activities and co-developing processes are turned into epistemological and ethical processes (Karlsen, Westerlund and Miettinen 2016). This implies, among other things, that we are constantly aware of the pitfalls of reproducing patterns of colonialism in which one institution may be seen as the valorized "giver" and the others as "receivers" (see e.g. Vaugeois 2007), and also that we recognize the "inner colonialism" that exists within the borders of our respective nation-

Westerlund, Heidi, and Sidsel Karlsen. 2017. Knowledge production beyond local and national blindspots: Remedying professional ocularcentrism of diversity in music teacher education. Action, Criticism, and Theory for Music Education 16 (3): 78-107.

doi:10.22176/act16.3.78 
states. In Nepal, for instance, political dynamics arise within the tensions between the civic form of nationalism and "ethnic nationalism" which emphasizes belongingness to particular ethnic communities. This has arisen from an awareness of how a small but ruling Hindu minority imposed its language, religion, and culture upon all other Nepali groups under the pretext of "national unity" (Shrestha 2007, 201). These political dynamics manifest not only through questions as to "what music is performed?" or "which instruments should be used in the classroom?" but above all, concerns for who is permitted to decide upon such matters in the first place.

Moreover, within the Global visions project, enacted interculturality may be seen as a heuristic conceptual tool employed to respond to the challenge of diversity and as an alternative guide for action when the framework of shared meanings no longer "works" (Komisarof and Hua 2016, 9). When interculturality is approached through the lens of knowledge production, as in the Global visions project, the acquisition of intercultural competences becomes a central concern. According to some of the leading scholars on interculturality in education, such competences may be understood in terms of attitudes, knowledge/comprehension, and skills (Deardorff and Jones 2012), including a "greater understanding of one's own identity" (285). In the context of music teacher education, this would mean a greater understanding of one's own identity as a music teacher and "adaptation, openness, and a willingness to change" (Gesche and Makeham 2010, 245). Although this goal for increasing self-understanding may also fit the common goals of internationalization in higher education, the concept of intercultural competences places knowledge production at the heart of interaction. However, for understanding occurrences of larger, institutional processes of knowledge creation, the framework of intercultural competences falls short and needs to be set "in juxtaposition and combination with other frames" (289), as it concentrates on the individual skill-base, leaving the dynamics of the socio-cultural and political context unquestioned (see also, Deardorff and Jones 2012, 285). In this sense, transnational co-construction of knowledge, which is the main goal of the Global visions project, can be viewed as an institutional intercultural process which, instead of aiming at understanding the culture of the other (teacher education unit), is concerned with professional culture making by changing boundary lines and exploring transformative dynamics of communication in music teacher education itself (see e.g. Sarmento 2016, 138). This way, the project also has the transcultural goal of producing hybrid professional knowledge, a

Westerlund, Heidi, and Sidsel Karlsen. 2017. Knowledge production beyond local and national blindspots: Remedying professional ocularcentrism of diversity in music teacher education. Action, Criticism, and Theory for Music Education 16 (3): 78-107.

doi:10.22176/act16.3.78 
form of knowledge that would not arise by itself in any of the contexts involved.

Central to our understanding of reflexivity is the acceptance of change as inevitable for all parties. Furthermore, in transnational institutional collaboration, such as between Finland and Nepal in our case, political correctness and critical views are unavoidably intertwined. On the one hand, we, as Nordic researchers, are painfully aware of the colonial setting of our project, in which we can be called the "sociologically privileged" professionals, having a certain kind of cultural capital and power over the teachers in Nepal (see Modood 2016, 255). Yet, despite the original wish of our institutional collaborators, we have refused to import simple "solutions" for the Nepali context; we understand that there is not a neutral space for us in any collaboration in Nepal. On the other hand, intercultural scholars have argued that while there may be a genuine wish to respect people's diverse values and their reasons for acting in particular ways, it does not mean "that these values cannot be misguided, fallacious or ideological" (Zotzmann 2016, 248). We may be convinced on ethical grounds that some practices might be better than others. For instance, some educational consultants of the Finnish Board of Education have fought against physical punishment in rural schools in Nepal by modelling for teachers that children's learning is possible without physical punishment. Further, the inequalities caused by caste distinctions that position most musicians to the lowest castes in their respective ethnic group prevail, although the caste system is not legally supported in Nepal. This social system also culturally legitimizes the power imbalance between some of our collaborators and ourselves. In addition, because of the caste system, some of the teachers are not in a position to make decisions as to how their institutional practices should be developed. Moreover, the exclusion of girls from music education, which takes place if following the heavily ritualized and male-dominated traditions, may be equally unjustifiable in contemporary Nepali communities who want to address the country's educational policy and the global ethical imperatives (Westerlund and Partti, in review) to work towards equality. Yet, there is all the more reason to be overly conscious that "culture can serve as an alibi, an invention, and a way of manipulating the other or a way of showing others implicitly that we are better than them" (4). Indeed, the core ethical values of our project researchers and participants are at stake (see Karlsen, Westerlund and Miettinen 2016).

Westerlund, Heidi, and Sidsel Karlsen. 2017. Knowledge production beyond local and national blindspots: Remedying professional ocularcentrism of diversity in music teacher education. Action, Criticism, and Theory for Music Education 16 (3): 78-107.

doi:10.22176/act16.3.78 
Hence, in the Global visions project this kind of complexity of transnational and intercultural knowledge construction means that the power relations need to be renegotiated and revised in each and every situation and through mutual interaction. Moreover, we need to accept that, as in collaborative learning in general, within mutual intercultural processes the institutional partners may each learn different things. In such a transnational institutional negotiation, there are no quick recipe-like approaches that music teacher education can provide for its teachers, researchers, or students, other than maintaining an increasing reflexivity and learning-by-doing towards the many issues and aspects that become part of the mutual interaction. While not accepting nihilism, we acknowledge that our own institutional practices are already complex, and this complexity may hide the complexity of the other from our vision. Indeed, according to Dervin and Gross (2016), "we can only reach a practical simplification of intercultural phenomena" (5), and we need to accept and recognize that (6):

- any approach to intercultural competence is ideological and political;

- the principle of "diverse diversities" should guide our understanding of intercultural competence;

- interaction and the negotiation of identities are central to intercultural competence;

- the continuum simple-complex should serve as a basis for work on intercultural competence; and

- discussions on and acceptance of failure should be included in "models" of intercultural competence.

Consequently, although challenges of difference might be solved, temporarily, in seemingly simple ways on the everyday and practical level, as scholars and teacher educators we cannot approach them by ocularcentrism without substantially damaging the vitality, richness, and vulnerability of the processes, the outcomes of the ongoing knowledge production, and the people partaking in it. Importantly, however, increased reflexivity does not assume that graduates, teachers, researchers or university professors would necessarily change their own values, and in this sense it does not assume ethical relativism. Hence, as research shows (Westerlund, Partti and Karlsen 2015; Zotzmann 2016, 252), cultural flexibility usually comes with emotional costs. Thus, focusing on musical expressions in a safe university classroom is likely

Westerlund, Heidi, and Sidsel Karlsen. 2017. Knowledge production beyond local and national blindspots: Remedying professional ocularcentrism of diversity in music teacher education. Action, Criticism, and Theory for Music Education 16 (3): 78-107.

doi:10.22176/act16.3.78 
to provide a rather narrow social and cultural platform for developing the coping strategies and resilience required when one's own ethical values are at stake and emotions and frustration take over. Given that future music teachers will have to face diverse diversities and rapid societal change on an everyday basis and in their own professional practices, understanding the complexity of intercultural negotiation should be an explicit goal for music teacher education, a goal that would require other educational means than world music courses to be achieved.

\section{Facing the paradoxes while co-developing the frames for knowledge-building professional communities}

At this early stage, our experiences from the activities in the Global visions project have already left us with quite a few paradoxes to reflect uponparadoxes that reveal not just the cultural but also the social-political differences framing music teacher education. In this way, these paradoxes also reveal how the ocularcentric multicultural approach may be misleading or irrelevant when transported from one context to another. Through the next four examples we illustrate how collaboration in transnational "third spaces" contests and complicates previous assumptions, why constant reflection between details and wider structures is needed when envisioning music teachers' education, and how production of diversity is always an ethicopolitical project.

\section{Understanding school as a local-national political project}

As Nepal is a country with hundreds of ethnic groups and musical traditions, we entered the discussions with our Nepali colleagues with the commonly held expectation that musical plurality is, and should be, written into the music curriculum and syllabi in a country like Nepal. To our surprise, however, many of the Kathmandu Valley private schools make significant efforts to create unity, for instance, through national-patriotic and school-specific musical repertoire. In a country with more than 100 ethnic groups, this "narrowing down" of the complexity and creating of shared values may be a logical educational response to the otherwise overwhelming cultural multiplicity, past political turbulences, civil war, and internal colonialism. Indeed, there may be a need to create a nation-state, "an imagined community" (Anderson 1991),

Westerlund, Heidi, and Sidsel Karlsen. 2017. Knowledge production beyond local and national blindspots: Remedying professional ocularcentrism of diversity in music teacher education. Action, Criticism, and Theory for Music Education 16 (3): 78-107.

doi:10.22176/act16.3.78 
through schooling, and music apparently is thought to play a role in this work, as it plays in many other countries. Yet the practice of creating unity in Nepali schools may be the residue of colonial school practices transported from other countries (e.g. from India). As many of the school principals in Kathmandu Valley private schools were educated in India (with a British colonial past), it is understandable that this kind of transnational colonial transportation takes place to some degree, as school is itself a kind of colonial form of socialization into society.

Without judging the school music in Kathmandu Valley private schools, in the Global visions project we need to remind ourselves that similar needs for unity were also found in some of the immigrant rich schools in Nordic countries, where diversities amongst the students created occasionally violent interaction (see Karlsen 2014). Indeed, in recent scholarship on interculturalism, it has been argued that globalisation may undermine the democracy and sovereignty of the nation-state (Cantle 2012), and it seems that this applies as well to multicultural music education scholarship. Employing a heterogenous understanding, we can then claim that the solution of creating unity through music is as legitimate as the one produced by the mainstream western multicultural paradigm, which holds widening diversity in curricula through cultural representations as a taken-for-granted value. Regarding school practices in Nepal, it is not the task of Nordic music educators to decide which forces should be recognized as hegemonic. Rather, we see that the future music teacher education program in Nepal could engage with these kinds of processes of reflexivity, just as Finnish music teacher education needs to contest the one-sided ocularcentric professional view of what immigrant students ought to experience in the Finnish school system.

\section{The difficulty in navigating local socio-cultural hierarchies}

Another example of the internal political dynamics of a music education context can be taken from the choice of musical instruments. For us, it was a surprise to see so many Western instruments in some of the private schools. The choice of instruments ranged from violins to electric pianos and guitars. In one of the schools, only the percussion instruments were from the region. While our first idea was that these instruments were brought by Westerners, one of the school principals explained that it was the children's parents who wished that the school use Western instruments in music lessons, as these

Westerlund, Heidi, and Sidsel Karlsen. 2017. Knowledge production beyond local and national blindspots: Remedying professional ocularcentrism of diversity in music teacher education. Action, Criticism, and Theory for Music Education 16 (3): 78-107.

doi:10.22176/act16.3.78 
instruments do not carry similar signifiers to musicians' low caste and to the specific ethnic contexts, as do the Nepali instruments. This is also why social mobility amongst the first generation of professional musicians is said to be possible mainly through hybrid combinations of Western popular music and traditional Nepali musical material (Grandin 2011).

Instrument choice unavoidably also affects envisioning of the music teacher program. Nepal has not fully established music as an independent school subject, and attempts to pave the way for music education in schools may also involve constructing novel identities that differ from those of traditional culture bearers. It is therefore understandable that it might be easier for the school to initiate music education and justify why music education is important equally for boys and girls when using instruments that are not associated with rituals in certain communities where they are used only by men, as is the case with many of the traditional Nepali instruments. A judgement based on a colonial critique would in this case miss the hard work that musicians and music educators need to do in a context where not so long ago it was also forbidden to play and learn another ethnic community's music (Westerlund and Partti in review) and where some still think that crossing cultural boundaries will destroy the future of the community. Yet another discussion is whether only Western people are allowed to learn from "the Others," and that these "Others" should just remain within the boundaries of their tradition, an idea that often creeps in as a consequence of the multicultural logic.

\section{The (im)possibility to avoid intervention in transnational 'third spaces'}

In the kinds of transnational/transcultural projects like Global visions, there will always be elements of both intended and unintended interventions that change the features of and dynamics between all parties involved. This applies as equally to us as it does to our Nepali partners. For instance, in one of our substudies, the researchers used Appreciative Inquiry to reduce biased views in the interviews. Yet, the innocent appreciative questions changed the practice in one of the schools in an unintended direction, as the once abandoned school song was added back after Global visions researchers had asked questions concerning this common practice.

Operating within a shared third-space environment and aiming to keep it open for expressing heterogeneous orientation also implies that different

Westerlund, Heidi, and Sidsel Karlsen. 2017. Knowledge production beyond local and national blindspots: Remedying professional ocularcentrism of diversity in music teacher education. Action, Criticism, and Theory for Music Education 16 (3): 78-107.

doi:10.22176/act16.3.78 
kinds of hierarchies clash as well as work under a number of unarticulated rules. While intervention implies a certain degree of imposition, this needs to be kept at arm's length, too, if we want to avoid contributing to the ocularcentrism of diversity fallacy in the work of producing shared knowledge. Rather, we need to ask time after time, over and over again: how can we challenge our own perception and appreciation of heterogeneity, for the sake of keeping our negotiations open, and how can the more global, ethical, and context-specific intersecting views be acknowledged?

4. Enhancing mutual reflexivity in and through the professional 'third space': Western colonialism or a human right?

There are many assumptions underlying teacher education that do not arise from any particular culture as such. In Finland, one of these is the understanding that teachers ought to be reflexive about their own backgrounds as well as those of their students. The original expectation of the Nepal Music Center was that teachers from the Sibelius Academy would teach their methods in order to aid the process of creating an effective music teacher education program in Nepal. Instead, after the exchange project ended, our main work has been to introduce teachers' co-reflection and reflexivity as a form of knowledge production through the two doctoral subprojects in Kathmandu. Shared collegial reflection, often conducted in relation to international literature of music education, was introduced as a tool for NMC teachers themselves to come up with, not just ideas on improved practices and a new study program, but also tools for developing wider reflexivity and producing knowledge together and with us. This practice, and a jointly organized conference in Kathmandu (CDIME XIII), also aimed to include the Nepali teachers into the wider international professional community of music educators in the long run. The act of co-reflection has been a new and time-consuming experience for Nepali teachers, and it is not identified as belonging to their tradition and working context, where repetition and imitation are central ways of learning and where decision-making is hierarchically organized. It has, however, already created an institutional rhythm for joint weekly teachers' meetings, during which the school's practices are developed through collegial discussion. The reading of international literature has revealed for the NMC teachers, for instance, how important it is to not change the current informal learning practices in the school's learning environments, as many other

Westerlund, Heidi, and Sidsel Karlsen. 2017. Knowledge production beyond local and national blindspots: Remedying professional ocularcentrism of diversity in music teacher education. Action, Criticism, and Theory for Music Education 16 (3): 78-107.

doi:10.22176/act16.3.78 
countries now try to develop similar practices. In our understanding, this kind of reflexivity aims to build wider teacher professionalism and organizational development, communities of knowledge-production, and more effective use of distributed expertise. However, from a multicultural perspective in which preservation of cultural heritage is preferred, one might ask what the ethical grounds are for expecting reflexivity to be the ideal of knowledge production in Nepal, in a context where such reflexivity may change the local hierarchies and organizational culture. Could reflection be seen as an unquestioned, modernist ocularcentric good if it critically targets the entire worldview of some people?

While engaging with the ethical ideas of the Indian-born Appadurai (2013), we believe that all music education professionals, including professionals in the majority world, have the right to develop reflexivity beyond national and local blindspots caused by various layers and forms of ocularcentrism, or colonialism for that matter. Such reflexivity does not center on understanding past traditions only, but needs to nurture ideas, aspirations, and development strategies for the future (Appadurai 2004). This means that music teacher education is formed and reformed, not simply based on the rules, principles, and values of the past-looking diverse musico-pedagogical practices of the given society; the profession needs to employ wider heterogeneous and kaleidoscopic reflexivity in envisioning the future. In our research activities, we have aimed to build collaborative settings in which all participants can see themselves as "co-authors" of their respective institutional practices; where a sense of collective ownership and identity is created equally between doctoral students and senior researchers, as with Finnish and Nepali teachers in everyday research practices by establishing co-learning as a shared goal and value. Consequently, we believe that transnational collaboration in music teacher education can strengthen the culture of aspiring, and thus a collective navigational capacity as it forces all participants to stop and think, over and over again, from multiple perspectives-to co-learn and continue to co-learn.

\section{Concluding thoughts}

In this article, we have argued that the multicultural music education movement, while beneficial to the field in many respects, encourages a too narrow, past-oriented, and one-sided "correct" understanding of diversity. Paradoxi-

Westerlund, Heidi, and Sidsel Karlsen. 2017. Knowledge production beyond local and national blindspots: Remedying professional ocularcentrism of diversity in music teacher education. Action, Criticism, and Theory for Music Education 16 (3): 78-107.

doi:10.22176/act16.3.78 
cally, while approaching diversities mainly from the perspective of liberty to lead freely chosen ways of life, as political multiculturalism does (Parekh 2016, 266), the movement may unintentionally increase cultural tensions through its ethnic labelling and strengthening of category borders. In this way, the approach may very well sustain segregation and preclude societal change and mobility, rather than serve as a remedy to inequality. By concentrating only on one context of transnational collaboration, we have suggested that codeveloping intercultural music teacher education might provide one possible way to break the dominating, panoptical approach of diversity. A more heterogenous and kaleidoscopic approach may allow for development of a wider ethical reflexivity and critical awareness of the paradoxes involved.

As a whole, the Global visions project tests the very idea of transnational institutional collaborative learning and the imagining of intercultural music teacher education through knowledge-production. Most importantly, in this kind of "third space" we need to learn to constantly ask: under what kinds of knowledge categories is music teacher education to be envisioned, and how are the politics of diversity in music teacher education addressed in the acts of envisioning? This implies that we, as researchers and collaborating teacher educators, need to develop the habit of constantly reviewing our own views from multiple perspectives, rather than developing firm conceptions of what is "correct" or when. At this point in the project, we can see that when perspectives of co-learning are turned into perspectives of knowledge production, we may be better able to welcome the ethical issues related to inter-institutional, cross-institutional, and cross-national collaboration. Instead of asking, "What can future music teachers learn from world musics?" we can ask, "What kind of knowledge should be co-produced in future music teacher education programs, and how can we become more conscious of our limited and conditioned views of diversity?" Thus far it is clear that the co-construction of intercultural music teacher education is not simply about the diversity of musics or even diverse pedagogies; it is about the ethics, politics, and ideologies of diversity that condition our understanding of diversity itself. We therefore agree with Gundara (2000), who defends the intercultural approach and claims that it is not the politicisation of education that is at stake, "but the recognition of the broader political context in which education takes place" (65). In such recognition, we believe that transnational engagement in music teacher education can offer a remedy, if even limited, to our ocularcentric local and national professional blindspots.

Westerlund, Heidi, and Sidsel Karlsen. 2017. Knowledge production beyond local and national blindspots: Remedying professional ocularcentrism of diversity in music teacher education. Action, Criticism, and Theory for Music Education 16 (3): 78-107.

doi:10.22176/act16.3.78 


\section{Acknowledgements}

This publication has been undertaken as part of the Global Visions through Mobilizing Networks project funded by the Academy of Finland (project no. 286162) as well as the ArtsEqual project funded by the Academy of Finland's Strategic Research Council from its Equality in Society programme (project no. 293199)

\section{About the Authors}

Heidi Westerlund is a professor at the Sibelius Academy, University of the Arts Helsinki, Finland, where she is also responsible for the music education doctoral studies. She has published widely in international journals and books and she is the co-editor of Collaborative learning in higher music education (Ashgate) as well as the Editor-in-chief of the Finnish Journal of Music Education. Her research interests include higher arts education, music teacher education, collaborative learning, cultural diversity and democracy in music education. She is currently leading two research projects funded by the Academy of Finland: The arts as public service: Strategic steps towards equality (2015-2020) and Global visions through mobilizing networks: Co-developing intercultural music teacher education in Finland, Israel and Nepal (20152019). Email: heidi.westerlund@uniarts.fi

Sidsel Karlsen is professor of music education and general education at Inland Norway University of Applied Sciences, and docent at the Sibelius Academy, University of the Arts Helsinki, Finland. She has published widely in international research journals and is a frequent contributor to international anthologies and handbooks. Her research interests include cultural diversity in music education, the interplay between formal and informal arenas for music learning, and the social and cultural significance of music festivals. Currently, she is one of two PIs of the research project Global visions through mobilizing networks: Co-developing intercultural music teacher education in Finland, Israel and Nepal (funded by the Academy of Finland 2015-2019). She is also part of the Musical gentrification and socio-cultural diversities project (funded by the Research Council of Norway 2013-2017). Email: sidsel. karlsen@inn.no

\section{References}

Abdallah-Pretceille, Martine. 2006. Interculturalism as a paradigm for thinking about diversity. Intercultural Education 17 (5): 475-83.

Ahonen, Pasi, and Janne Tienari. 2015. Ethico-politics of diversity and its production. In The Routledge Companion to Ethics, Politics and Organization, edited by Alison Pullen, and Carl Rhodes, 271-87. New York: Routledge.

Westerlund, Heidi, and Sidsel Karlsen. 2017. Knowledge production beyond local and national blindspots: Remedying professional ocularcentrism of diversity in music teacher education. Action, Criticism, and Theory for Music Education 16 (3): 78-107.

doi:10.22176/act16.3.78 
Anderson, Benedict. 1991. Imagined communities: Reflections on the origin and spread of nationalism (rev. ed., 1983). London: Verso.

Appadurai, Arjun. 2004. The capacity to aspire: Culture and the terms of recognition. In Culture and public action, edited by Vijayendra Rao, and Michael Walton, 59-84. Stanford: Stanford University Press.

Appadurai, Arjun. 2013. The future as cultural fact: Essays on the global condition. London: Verso.

Bauman, Zygmunt. 2010. 44 letters from the liquid modern world. Malden: Polity Press.

Bauman, Zygmunt. 2011. Culture in a liquid modern world. Malden: Polity Press.

Bhabha, Homi. 1994. The location of culture. New York: Routledge.

Bradley, Deborah. 2007. The sounds of silence: Talking race in music education. Action, Criticism, and Theory for Music Education 6 (4): 132-62.

Bradley, Deborah. 2015. The dynamics of multiculturalism in Music Matters: A Philosophy of Music Education. Action, Criticism, and Theory for $\mathrm{Mu}$ sic Education 14 (3): 10-26.

Campbell, Patricia S. 2004. Teaching music globally: Experiencing music, expressing culture. New York: Oxford University Press.

Campbell, Patricia S., John Drummond, Peter Dunbar-Hall, Keith Howard, Huib Schippers, and Trevor Wiggins, eds. 2005. Cultural diversity in music education: Directions and challenges for the 21st century. Bowen Hills: Australian Academic Press.

Cantle, Ted. 2012. Interculturalism: The new era of cohesion and diversity. Basingstoke: Palgrave Macmillan.

Castells, Manuel. 2010. The power of identity. 2nd edition. Oxford: WileyBlackwell.

Darling-Hammond, Linda, and Ann Lieberman. 2012. Teacher education around the world: What can we learn from international practice? In Teacher education around the world: Changing policies and practices, edited by Linda Darling-Hammond, and Ann Lieberman, 151-69. London: Routledge.

Dasen, Pierre R. and Abdeljalil Akkari. 2008. Introduction: Ethnocentrism in education and how to overcome it. In Educational theories and practices

Westerlund, Heidi, and Sidsel Karlsen. 2017. Knowledge production beyond local and national blindspots: Remedying professional ocularcentrism of diversity in music teacher education. Action, Criticism, and Theory for Music Education 16 (3): 78-107.

doi:10.22176/act16.3.78 
from the majority world, edited by Pierre R. Dasen and Abdeljalil Akkari, 7-23. New Delhi, India: Sage.

Deardorff, Darla K., and Elspeth Jones. 2012. Intercultural competence: An emerging focus in post-secondary education. In The Sage handbook of international higher education, edited by Darla K. Deardorff, Hans de Wit, John Heyl, and Tony Adam, 283-303. Thousand Oaks: Sage Publications.

Dervin, Fred, and Zehavit Gross. 2016. Introduction: Towards the simultaneity of intercultural competence. In Intercultural competence in education: Alternative approaches for different times, edited by Fred Dervin and Zehavit Gross, 1-10. London: Palgrave Macmillan.

Elliott, David. 1995. Music matters. A new philosophy of music education. Oxford: Oxford University Press.

Elliott, David J., and Marissa Silverman. 2015. Music matters: A philosophy of music education. 2nd edition. New York: Oxford University Press.

Fishman, Barry J., Elizabeth Davis, and Carol K. K. Chan. 2014. A learning sciences perspective on teacher learning research. In The Cambridge handbook of the learning sciences, edited by R. Keith Sawyer, 707-25. Cambridge: Cambridge University Press.

Foucault, Michel. 1977. Discipline and punish: The birth of the prison. Translated by Alan Sheridan. New York: Vintage Books.

Georgii-Hemming, Eva, Pamela Burnard, and Sven-Erik Holgersen, eds. 2013. Professional knowledge in music teacher education. Farnham: Ashgate.

Gesche, Astrid H, and Paul Makeham. 2010. Creating conditions for intercultural and international learning and teaching. In Researching international pedagogies. Sustainable practice for teaching and learning in higher education, edited by Meeri Hellstén and Anna Reid, 241-58. London, UK: Springer.

Grandin, Ingemar. 2011. Music and media in local life: Music practice in a Newar neighbourhood in Nepal, revised ed. Kathmandu: Mandala Book Point. (Orig. 1989).

Gundara, Jagdish S. 2000. Interculturalism, education and inclusion. London: Sage Publications.

Harris, Diana. 2006. Music education and Muslims. Stoke on Trent: Trentham Books.

Westerlund, Heidi, and Sidsel Karlsen. 2017. Knowledge production beyond local and national blindspots: Remedying professional ocularcentrism of diversity in music teacher education. Action, Criticism, and Theory for Music Education 16 (3): 78-107.

doi:10.22176/act16.3.78 
Hess, Juliet. 2013. Performing tolerance and curriculum: The politics of selfcongratulation, identity formation, and pedagogy in world music education. Philosophy of Music Education Review 21 (1): 66-91.

Hess, Juliet. 2015. Upping the "anti-“: The value of an anti-racist theoretical framework in music education. Action, Criticism, and Theory for Music Education 14 (1): 66-92.

Howard, Karen, Matt Swanson, and Patricia S. Campbell. 2014. The diversification of music teacher education: Six vignettes from a movement in progress. Journal of Music Teacher Education 24 (1): 26-37.

Karlsen, Sidsel. 2013. Immigrant students and the "homeland music": Meanings, negotiations and implications. Research Studies in Music Education 35 (2): 161-77.

Karlsen, Sidsel. 2014. Exploring democracy: Nordic music teachers' approaches to the development of immigrant students' musical agency. International Journal of Music Education 32 (4): 422-36.

Karlsen, Sidsel. 2017. Policy, access and multicultural (music) education. In Policy and the political life of music education: Standpoint for understanding and action, edited by Patrick Schmidt and Richard Colwell, 21130. New York: Oxford University Press.

Karlsen, Sidsel, and Heidi Westerlund. 2015. Music teachers' repertoire choices and the quest for solidarity: Opening arenas for the art of living with difference. In The Oxford handbook of social justice in music education, edited by Cathy Benedict, Patrick Schmidt, Gary Spruce, and Paul Woodford, 372-87. New York: Oxford University Press.

Karlsen, Sidsel, Heidi Westerlund, and Laura Miettinen. 2016. Intercultural practice as research in music education: The imperative of an ethics-based rationale. In The Routledge international handbook of intercultural arts research, edited by Pamela Burnard, Elizabeth Mackinlay, and Kimberly Powell, 369-79. New York: Routledge.

Keuchel, Susanne. 2015. Arts education in the age of cultural diversity: A basis to gain cultural identity in a risk society. In Arts education beyond art: Teaching art in times of change, edited by Barend van Heusden and Pascal Gielen, 94-111. Amsterdam: Antennae.

Komisarof, Adam, and Zhu Hua. 2016. Introduction. In Crossing boundaries and weaving intercultural work, life, and scholarship in globalizing universities, edited by Adam Komisarof and Zhu Hua, 1-20. New York: Routledge.

Westerlund, Heidi, and Sidsel Karlsen. 2017. Knowledge production beyond local and national blindspots: Remedying professional ocularcentrism of diversity in music teacher education. Action, Criticism, and Theory for Music Education 16 (3): 78-107.

doi:10.22176/act16.3.78 
Kymlicka, Will. 2010. The rise and fall of multiculturalism? New debates on inclusion and accommodation in diverse societies. International Social Science Journal 61 (199): 97-112.

Laes, Tuulikki. 2017. The (im)possibility of inclusion. Reimagining the potentials of democratic inclusion in and through activist music education. Sibelius Academy of the University of the Arts Helsinki. Studia Musica 72.

Laes, Tuulikki, and Heidi Westerlund. 2017. Performing disability in music teacher education: Moving beyond inclusion through expanded professionalism. International Journal of Music Education. Online first: May 14. https://doi.org/10.1177/0255761417703782

Loobuyck, Patrick. 2016. Towards an intercultural sense of belonging together: Reflections on the theoretical and political level. In Multiculturalism and interculturalism: Debating the dividing lines, edited by Nasar Meer, Tariq Modood, and Ricard Zapata-Barrero, 225-45. Edinburgh: Edinburgh University Press.

Meer, Nasar, and Tariq Modood. 2016. Interculturalism, multiculturalism and citizenship. In Multiculturalism and interculturalism: Debating the dividing lines, edited by Nasar Meer, Tariq Modood, and Ricard ZapataBarrero, 27-52. Edinburgh: Edinburgh University Press.

Meer, Nasar, Tariq Modood, and Ricard Zapata-Barrero. 2016. A plural century: Situating interculturalism and multiculturalism. In Multiculturalism and interculturalism: Debating the dividing lines, edited by Nasar Meer, Tariq Modood, and Ricard Zapata-Barrero, 1-26. Edinburgh: Edinburgh University Press.

Miettinen, Laura, Claudia Gluschankof, and Heidi Westerlund. 2016. Envisioning intercultural music teacher education in a time of uncertainty. Presented at the International Society for Music Education 32nd (ISME) World Conference, Glasgow, Scotland.

Modood, Tariq. 2012. Post-immigration "difference" and integration: The case of Muslims in Western Europe. London: The British Academy.

Olson, Christa, and James Peacock. 2012. Globalism and interculturalism: Where global and local meet. In The Sage handbook of international higher education, edited by Darla K. Deardorff, Hans de Wit, John Heyl, and Tony Adams, 305-22. Thousand Oaks: Sage Publications.

Parekh, Bhikhu. 200o. Rethinking multiculturalism: Cultural diversity and political theory. Basingstoke: Macmillan.

Parekh, Bhikhu. 2016. Afterword: Multiculturalism and interculturalism-A critical dialogue. In Multiculturalism and interculturalism: Debating the

Westerlund, Heidi, and Sidsel Karlsen. 2017. Knowledge production beyond local and national blindspots: Remedying professional ocularcentrism of diversity in music teacher education. Action, Criticism, and Theory for Music Education 16 (3): 78-107.

doi:10.22176/act16.3.78 
dividing lines, edited by Nasar Meer, Tariq Modood, and Ricard ZapataBarrero, 266-79. Edinburgh: Edinburgh University Press.

Roberts, J. Christopher, and Patricia S. Campbell. 2015. Multiculturalism and social justice: Complementary movements for education in and through music. In The Oxford handbook of social justice in music education, edited by Cathy Benedict, Patrick Schmidt, Gary Spruce, and Paul Woodford, 272-86. New York: Oxford University Press.

Sarmento, Clara. 2016. Intercultural polyphonies against the "death of multiculturalism": Concepts, practices and dialogues. In Intercultural competence in education: Alternative approaches for different times, edited by Fred Dervin, and Zehavit Gross, 121-41. London: Palgrave Macmillan.

Schippers, Huib. 2010. Facing the music: Shaping music education from a global perspective. New York: Oxford University Press.

Shah, Iman, Rizu Tuladhar, John Shrestha, and Kushal Karki. 2017. Codeveloping music education through reflexivity and exchange in the context of Nepal. Presented at Cultural Diversity in Music Education Conference XIII, Kathmandu, Nepal.

Shrestha, Bal G. 2007. Ethnic nationalism in Nepal and the Newars. In Contentious politics and democratization in Nepal, edited by Mahendra Lawoti, 199-224. Los Angeles: Sage Publishing.

Swanwick, Keith. 1988. Music, mind, and education. London and New York: Routledge.

Timonen, Vilma, Marja-Leena Juntunen, and Heidi Westerlund. 2017. Colonialism or empowerment? Exploring teacher reflexivity in a Nepalese music school context. Presented at Cultural Diversity in Music Education Conference XIII, Kathmandu, Nepal.

Treacy, Danielle Shannon, Suyash Neupane, and Sapna Thapa. 2017. Cultural renewal and change: The role of global influences in Nepali music and music education. Presented at Cultural Diversity in Music Education Conference XIII, Kathmandu, Nepal.

Treacy, Danielle Shannon, Vilma Timonen, Alexis Anja Kallio, and Iman Shah (forthcoming). Imagining beyond ends-in-view: The ethics of assessment as valuation in Nepali music education. In Oxford handbook of philosophical and qualitative perspectives on assessment in music education, edited by David J. Elliott, Marissa Silverman, and Gary McPherson. New York: Oxford University Press.

UNESCO. 2008. World report investing in cultural diversity and intercultural dialogue. Luxembourg: UNESCO.

Westerlund, Heidi, and Sidsel Karlsen. 2017. Knowledge production beyond local and national blindspots: Remedying professional ocularcentrism of diversity in music teacher education. Action, Criticism, and Theory for Music Education 16 (3): 78-107.

doi:10.22176/act16.3.78 
Vaugeois, Lise. 2007. Social justice and music education: Claiming the space of music education as a site of postcolonial contestation. Action, Criticism, and Theory for Music Education 6 (4): 163-200.

Vertovec, Steven. 2007. Super-diversity and its implications. Ethnic and Racial Studies 30 (6): 1024-54.

Volk, Theresa M. 1998. Music education and multiculturalism: Foundations and principles. New York: Oxford University Press.

Westerlund, Heidi. 2002. Bridging experience, action and culture in music education. Studia Musica 16. Helsinki: Sibelius Academy.

Westerlund, Heidi. 2017. Visions for intercultural teacher identity in 21stcentury superdiverse societies. In Building intercultural and interdisciplinary bridges: Where theory meets research and practice, edited by Pamela Burnard, Valerie Ross, Helen Julia Minors, Kimberly Powell, Tatjana Dragovic and Elizabeth Mackinlay, 12-19. BIBACC Publishing.

Westerlund, Heidi, and Heidi Partti. Submitted. A case of a cosmopolitan culture bearer as an activist: Striving for gender inclusion in Nepali music education. International Journal of Music Education.

Westerlund, Heidi, Heidi Partti, and Sidsel Karlsen. 2015. Teaching as improvisational experience: Student music teachers' reflections on learning during an intercultural project. Research Studies in Music Education 37 (1): $55-75$.

Zapata-Barrero, Ricard. 2016. Exploring the foundations of the intercultural policy paradigm: A comprehensive approach. Identities: Global Studies in Culture and Power 23 (2): 155-73.

Zotzmann, Karin. 2016. Intercultural competence: Value disembedding and hyper-flexibility. In Intercultural competence in education: Alternative approaches for different times, edited by Fred Dervin, and Zehavit Gross, 237-57. London: Palgrave Macmillan.

\section{Notes}

${ }^{1}$ The term majority world is used as a synonym of "non-Western" and refers to the majority of the world's population. Its purpose is to challenge Western ethnocentrism and to avoid the polarization between the North and South or politically incorrect terms as "the Third World" or "developing countries" (see, e.g., Dasen and Akkari 2008, 9).

${ }^{2}$ For more information about the research project, see: http://sites.uniarts.fi/ web/globalvisions

Westerlund, Heidi, and Sidsel Karlsen. 2017. Knowledge production beyond local and national blindspots: Remedying professional ocularcentrism of diversity in music teacher education. Action, Criticism, and Theory for Music Education 16 (3): 78-107.

doi:10.22176/act16.3.78 